\title{
Analyses of Factors to Affect the Bioassay System Using Luminescent Bacterium Vibrio fischeri
}

\author{
Shinichi Nagata* and Xiaojian Zhou \\ Environmental Biochemistry Group, Research Center for Inland Seas, Kobe University, 5-1-1 Fukaeminami, Higashinada, Kobe 658- \\ 0022, Japan
}

(Received May 16, 2005; Accepted September 14, 2005)

\begin{abstract}
Analytical conditions for evaluating the chemical toxicity were examined using luminescent bacterium Vibrio fischeri (V. fischeri) deutsche sammluing von microorganismen (DSM) 7151, taking the medium composition into consideration. The manipulation of the cells for optimal assay was obtained as follows; the cells were grown in luminescence (LM) medium containing $3 \mathrm{~g} / \mathrm{l}$ of glycerol for $18 \mathrm{hr}$. They were washed twice with artificial seawater (ASW) and then diluted about 128 folds by ASW, corresponding to 1.0-1.5 × $10^{6} \mathrm{cfu} / \mathrm{ml}$. Using 4,5-dichloro-2-(noctyl)-4-isothiazolin-3-one (SeaNine 211) as a representative toxic chemical, we evaluated the extent of its toxicity in terms of present method, where $50 \%$ effective concentration $\left(\mathrm{EC}_{50}\right)$ resulted in 0.51 and $0.35 \mathrm{mg} / \mathrm{l}$ at 15 and $30 \mathrm{~min}$ of incubations, respectively. Sensitivity of present assay was higher than those of traditional ones by over 2 folds from the comparison of $\mathrm{EC}_{50}$ for $\mathrm{Cu}^{2+}$. The results show that the present assay using freshly cultured $V$. fischeri has not only high sensitivity and reproducibility but also simplicity to estimate the contamination by chemicals.
\end{abstract}

Key words — Vibrio fischeri DSM 7151, bioluminescence, bioassay, 4,5-dichloro-2-(n-octyl)-4-isothiazolin-3one

\section{INTRODUCTION}

Bioluminescence is the light produced by some organisms mediated via the enzyme luciferase or a photoprotein mediated by an oxidation reaction. ${ }^{1)}$ Light emission from bioluminescent bacteria is the result functioned by bacterial luciferase, a flavin monooxygenase that catalyzes the following reaction: $\mathrm{FMNH}_{2}+\mathrm{O}_{2}+\mathrm{RCHO} \rightarrow h v+\mathrm{FMN}+\mathrm{H}_{2} \mathrm{O}+$ $\mathrm{RCOOH}$, in which long-chain fatty acid is produced from its aldehyde through oxidation of $\mathrm{FMNH}_{2}$ to FMN. ${ }^{2)}$ Vibrio fischeri (V. fischeri) is a bioluminescent bacterium found in marine habitats where there exists specific symbiont phenomena as the lightemitting organ of the sepiolid squid Euprymna scolopes. ${ }^{3)}$ Bioluminescence emitted from V. fischeri at around $485 \mathrm{~nm}$ can be detected with an adapted detector such as photomultiplier, photodiode, sensitive film, and luminescence reader with multi-well plates, the latter of which is convenient assay to

\footnotetext{
*To whom correspondence should be addressed: Environmental Biochemistry Group, Research Center for Inland Seas, Kobe University, 5-1-1 Fukaeminami, Higashinada, Kobe 658-0022, Japan. Tel. \& Fax: +81-78-431-6342; E-mail: nagata@maritime. kobe-u.ac.jp
}

check cell viability using Bactiter-Glo.,4)

Since light emission of $V$. fischeri is strictly linked to its cellular respiration, any disruption of normal metabolism in cells causes a decrease in light intensity. ${ }^{5,6)}$ In addition, only when their surrounding environment is not polluted, light emission is possibly carried out in $V$. fischeri ${ }^{7}{ }^{7}$ such characteristics of which led to the possibility to detect the changes in bioluminescence intensity (BLI) caused by pollutants. ${ }^{8-10)}$ The bioassay using luminescence of $V$. fischeri has been extensively applied in toxicity assessments due to higher sensitivity, lower cost of implementation, easier operation in comparison with other methods based on nitrification inhibition, respirometry, ATP luminescence and inhibition of enzyme activities. ${ }^{11)}$

Bioassay systems using the emitted luminescence of $V$. fischeri have been performed by using commercial kits such as Micotox ${ }^{\mathrm{TM}}$ or ABOATox ${ }^{\mathrm{TM}}$, where the standard conditions for testing were given as follows; $15^{\circ} \mathrm{C}, 2 \% \mathrm{NaCl}$, and about 7.0 as the temperature, salinity, and $\mathrm{pH}$, respectively. Since these conditions are often different from those of actual sampling sites such as river or marine environments, it seems to be suspensive to regard these data obtained from this protocol as real toxicity. ${ }^{12,13)}$ 
Furthermore, BLI of test kits' reagents tends to be decreased accompanied with the increase of storage time.

Owing to these reasons, some studies have been made to achieve a greater flexibility in the selection of an appropriate test system for the assessments of environmental toxicity. ${ }^{14)}$ Thus, the substitutable and flexible methods under similar conditions as natural environment have been expected to provide more accurate evaluation for pollutants. ${ }^{11)}$ According to previous studies, manipulation of cells have been discussed whether medium components should be eliminated to avoid its interference of cellular activity although Lajoie et al. claimed no requirement of cell washing. ${ }^{15-19)}$ Thus, it seems to be of value to address the confirmation of assay system through fundamental analyses of several kinds of conditions.

In the present study, therefore, we tried to clarify the suitable conditions of the bioluminescent assay using $V$. fischeri with the aim of practical applicability to detect the toxicity of chemicals sensitively. Particularly, we focused on the influence of $\mathrm{NaCl}$ concentrations against the sensitivity of present method, since environmental samples possess wide concentration ranges of $\mathrm{NaCl}$ and $V$. fischeri is marine bacterium to require $\mathrm{NaCl}$ for its optimal activity.

\section{MATERIALS AND METHODS}

Culture Conditions

A strain used in this study was $V$. fischeri deutsche sammluing von microorganismen (DSM) 7151, which was grown in two kinds of media. One was a LB medium which contains $0.5 \%$ yeast extract (Difco Laboratories, Detroit, MI, U.S.A.), 1.0\% tryptone (Difco Laboratories), and $0.5 \mathrm{M} \mathrm{NaCl}$. The other was luminescence (LM) medium, in which $0.5 \%$ yeast extract (Difco Laboratories), $0.5 \%$ tryptone (Difco Laboratories), $0.1 \% \mathrm{CaCO}_{3}$, and $0.3 \%$ glycerol were involved in artificial seawater (ASW, JIS K-2510) in place of actual seawater used in original LM medium. $\mathrm{pH}$ of both media was adjusted to 7.0 by $\mathrm{NaOH}$. The cells were incubated in media with a rotary shaker $(120 \mathrm{rpm})$ at $30^{\circ} \mathrm{C}$ by adding $1 \%(\mathrm{v} / \mathrm{v})$ of pre-cultures with 13 and $24 \mathrm{hr}$ of incubations in LB and LM media, respectively. Growth was determined by measuring optical density at $650 \mathrm{~nm}\left(\mathrm{OD}_{650}\right)$ using a spectrophotometer (DU 640, Beckman, Fullerton, CA, U.S.A.).

Bioluminescence Measurements The cells grown in both media were taken up at an appropriate time and subsequently separated by centrifugation $\left(10000 \times g, 1 \mathrm{~min}, 4^{\circ} \mathrm{C}\right)$, followed by washing with $0.5 \mathrm{M} \mathrm{NaCl}$ or ASW. BLI was measured for 0.1 min integral time by luminescence reader (BLR201, Aloka, Tokyo, Japan). Cell suspensions were prepared as either 0.2 or $0.5 \mathrm{ml}$ volume in liquid scintillation vial (Wheaton, Millville, NJ, U.S.A.), each of which corresponds to higher and lower cell densities, respectively.

As toxic chemicals, we used 4,5-dichloro-2-(noctyl)-4-isothiazolin-3-one (SeaNine 211), $\mathrm{CuSO}_{4}$, tributyltin chloride (TBT-Cl), 3-iodo-2-propynyl butylcarbamate (IPBC), and 2-methylthio-4-tertbutylamino-6-cyclopropylamino-s-triazine (Irgarol 1051). The efficacy and mechanism of them are as follows; Toxic effect of $\mathrm{Cu}^{2+}$ is suppression of mitosis through glutathione reduction and destroy of cellular defense against oxygen-free radicals. ${ }^{20)}$ SeaNine 211 is typical inhibitor for settlements of bacteria and algae. TBT is well known as one of the most significant hazardous compounds to aquatic organisms through neurotoxic, hepatotoxic, immunosuppressive and hormone disruptive activities. ${ }^{21)}$ In addition, Irgarol and IPBC are inhibitors for photosystem- $\mathrm{II}^{5}$ and for acetylcholinesterase on animals, ${ }^{22}$ ) respectively.

Each chemical dissolved in dimethyl sulfoxide (DMSO) were added to the cell suspension at final concentration of $1 \%$. At the same time, we prepared control without chemicals, for both of which the changes of BLI were followed.

Calculations — To determine the toxicity of chemicals to $V$. fischeri, percentage of inhibition efficiency [INH (\%)] was used in this study. The values of INH (\%) were calculated from BLI changes between samples and controls as follows;

$$
I N H(\%)=\left[1-\left(\frac{I T_{t} \times I C_{0}}{I T_{0} \times I C_{t}}\right)\right] \times 100
$$

where INH (\%): Percentage of INH.

$\mathrm{IT}_{\mathrm{t}}$ : BLI of the sample after the contact time ( $\mathrm{t}$ ) with chemicals.

$\mathrm{IT}_{0}$ : Initial BLI of the sample.

$I_{\mathrm{t}}$ : BLI of the control after incubation time $(\mathrm{t})$.

$\mathrm{IC}_{0}$ : Initial BLI of the control.

The data of INH (\%) in this text are the averages of at least two independent measurements. The value of $50 \%$ effective concentration $\left(\mathrm{EC}_{50}\right)$ was obtained as the concentration corresponding to INH $(\%)=50$ in the relationship between INH (\%) and concentration of chemicals. 

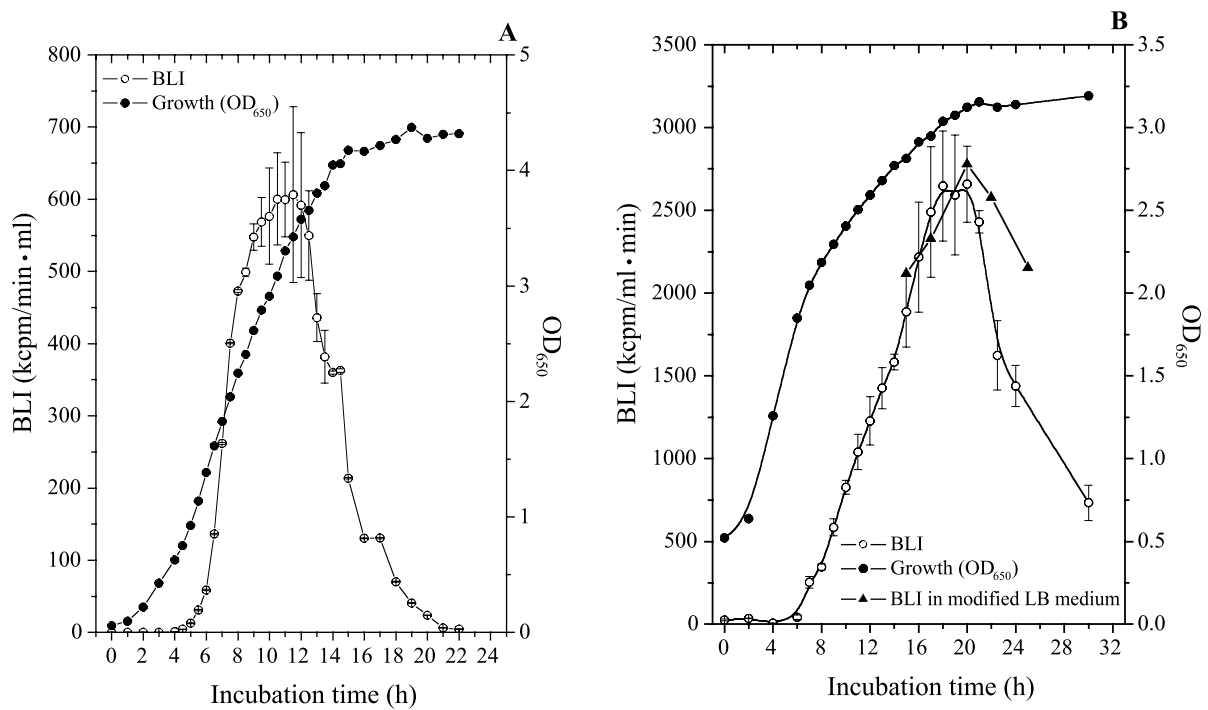

Fig. 1. Changes of BLI and Growth of V. fischeri

BLI and growth of $V$. fischeri in LB (A) and LM media (B) were followed by luminescence reader and spectrophotometer as a function of the incubation time, respectively. The former and the latter were expressed as open and closed circles, respectively. As a reference, BLI of cells grown in LB medium containing glycerol and $\mathrm{CaCO}_{3}$ in $\mathrm{ASW}$ was also described as closed triangles. Both BLI and turbidities at $650 \mathrm{~nm}\left(\mathrm{OD}_{650}\right)$ described here were the averages with and without standard deviations from three independent incubations, respectivery.

\section{RESULTS AND DISCUSSION}

\section{Growth Condition of $V$. fischeri for High Inten- sity of Bioluminescence}

When the cells were grown in a LB medium, they reached the stationary phase of growth after 14$18 \mathrm{hr}$ of incubation. Bioluminescence emission from the cells was observed accompanied with cell growth, as shown in Fig. 1A. Incubation time of 11$12 \mathrm{hr}$ afforded the maximum of BLI and longer incubation time, $>12 \mathrm{hr}$, led to rapid decrease. Similar tendency was observed in a LM medium, in which BLI increased with the incubation time and attained at maximum at $18-22 \mathrm{hr}$ of incubation, as shown in Fig. 1B. The incubation time to reach the maximum of BLI in LM medium was different from that of LB medium. In addition, BLI from the cells grown in LM medium resulted in four-fold higher than that in LB medium.

The difference of composition between two media is mainly regarded as the inclusion of glycerol and $\mathrm{CaCO}_{3}$ in $\mathrm{LM}$ medium. In addition, ASW was used in $\mathrm{LM}$ medium in place of $0.5 \mathrm{M} \mathrm{NaCl}$ in LB medium. About these different factors, first we tried to examine the effect of glycerol in growth medium to clarify the stimulative effect on BLI of the present strain DSM 7151. As shown in Fig. 2, the cells grown in both LB and LM media had enhanced BLI with the increase of glycerol concentra-

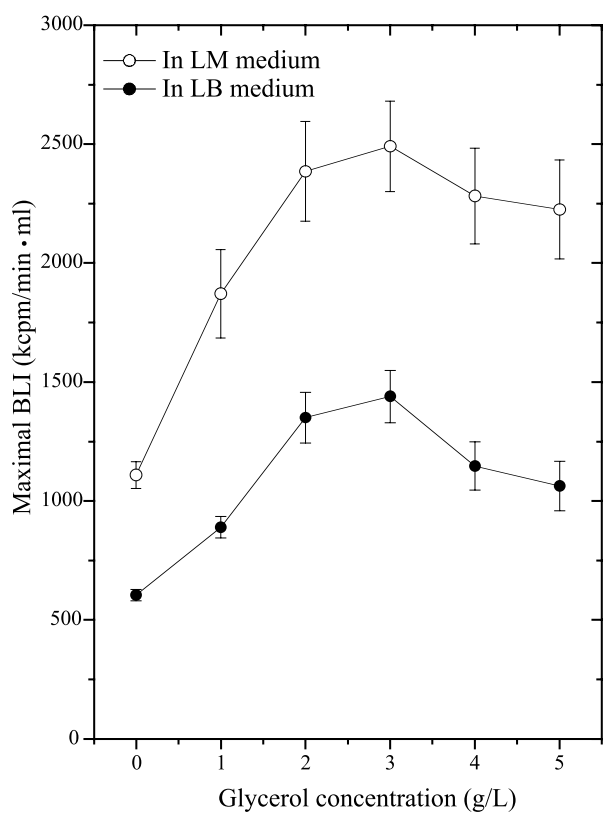

Fig. 2. Effect of Glycerol Concentration on BLI of V. fischeri Grown in LB and LM media

Supplementary effect of glycerol $(0,1,2,3,4$, and $5 \mathrm{~g} / \mathrm{l})$ was examined for cell growth in both LB medium and original LM medium without glycerol. BLI of $0.2 \mathrm{ml}$ cell culture was measured for $0.1 \mathrm{~min}$ integral time in the luminescence reader and maximal BLI in the incubation was used for this measurements. The values of BLI in LM (open circles) and LB (closed circles) media were described by the averages with standard deviations from three independent experiments. 
Table 1. Effect of Medium Composition on BLI of $V$. fischeri

\begin{tabular}{lcc}
\hline \hline Medium & $\begin{array}{c}\text { Maximal BLI } \\
(\mathrm{kcpm} / \mathrm{ml} \cdot \mathrm{min})\end{array}$ & Enhancement folds \\
\hline $\mathrm{LB}$ & $600(11)$ & 1.00 \\
$\mathrm{LB}+$ Glycerol & $1428(15)$ & 2.38 \\
$\mathrm{LB}+$ Glycerol $+\mathrm{CaCO}_{3}$ & $2007(16)$ & 3.35 \\
$\mathrm{LB}+$ Glycerol $+\mathrm{CaCO}_{3}+\mathrm{ASW}$ & $2777(20)$ & 4.63 \\
$\mathrm{LM}$ & $2657(20)$ & 4.43 \\
\hline
\end{tabular}

a) Values in parentheses indicate the incubation time to reach maximal BLI (hr).

tion in medium. The addition of glycerol led to over 2 folds higher BLI compared to those without addition of glycerol for both media, in which the maximum was observed in the presence of $3 \mathrm{~g} / \mathrm{l}$ of glycerol. To make clear the difference of both media, we analyzed in detail BLI of the cells grown in LB medium, in which bioluminescence maximum of cells grown with glycerol was enhanced by 2.4 folds compared to that without glycerol, as shown in Table 1.

Next, the effects of $\mathrm{CaCO}_{3}$ addition as well as the usage of ASW in place of $0.5 \mathrm{M} \mathrm{NaCl}$ were examined. With an increase of $\mathrm{CaCO}_{3}$ concentration in LB medium BLI of the cells increased until $1 \mathrm{~g} / \mathrm{l}$, but it became constant over $1 \mathrm{~g} / \mathrm{l}$ of $\mathrm{CaCO}_{3}$ (data not shown). The addition of $1 \mathrm{~g} / \mathrm{l}$ of $\mathrm{CaCO}_{3}$ brought about 1.5 folds enhancement of BLI as shown in Table 1. Furthermore, BLI increased from 2000 to $2800 \mathrm{kcpm} / \mathrm{ml} \cdot \mathrm{min}$, if ASW was used in place of $0.5 \mathrm{M} \mathrm{NaCl}$ in LB medium (Table 1). Thus it became evident that the addition of glycerol and $\mathrm{CaCO}_{3}$ as well as the usage of ASW led to significant increase of BLI of the strain DSM 7151. It seems to be of value to note that the use of different concentration of tryptone in both media, 5 and $10 \mathrm{~g} / \mathrm{l}$ in LM and LB media, respectively, was negligible, since little difference of BLI was observed in the cells grown in LM medium and LB medium with $0.3 \%$ glycerol and $0.1 \% \mathrm{CaCO}_{3}$ in $\mathrm{ASW}$ as shown in Fig. 1B.

To use the present bioassay efficiently, BLI of V. fischeri DSM 7151 should be stable and relatively high to get reliable data, which leads to high sensitivity in the real toxicity accompanied with improved signal to noise ratios. ${ }^{13)}$ The utilization of LM medium for growth brought about feasible conditions to obtain high BLI for the present strain DSM 7151. Taking the steep decrease of BLI after $22 \mathrm{hr}$ of incubation into consideration, cells grown in LM medium for $18 \mathrm{hr}$ are recommended to be used for the achievement of the most suitable and sensitive assay.

\section{Interference Effect of Medium Composition}

An attempt was made to determine how the cells with active luminescent ability should be manipulated. Ren et al. showed that the color of growth medium affected some sensitivity of luminescent bacteria unless medium compositions were eliminated before use. ${ }^{17,18)}$ In this connection, we examined the influence of medium components by using the cells diluted by 100 folds with growth medium freshly prepared as well as with ASW. For sensitivity comparison, we used $0.3 \mathrm{mg} / \mathrm{l}$ of SeaNine 211 which is lower than the following concentration of $0.4 \mathrm{mg} / \mathrm{l}$. As shown in Fig. 3, INH (\%) in the cells diluted by fresh medium and ASW resulted in 16 and $23 \%$ at $30 \mathrm{~min}$ of incubation, respectively (Fig. 3, a and b). That is to say, systems possessing high portions of medium components showed low sensitivity. In addition, it appears to be of interest to point out that inhibition percentages were constant or rather reduced with an increase of the incubation time, suggesting that there might be some problems to affect the sensitivity if medium components are included.

To determine the interference effect of medium components on the sensitivity of present bioassay system, we tried to eliminate them more perfectly through washing processes. The cultured cells after centrifugation were suspended in ASW, which still contained medium components (Fig. 3, c). After 30 min of incubation we observed the enhancement of sensitivity through centrifugation and the use of ASW, from 23 to $30 \%$, as realized from the comparison of $b$ and $c$ in Fig. 3. By increasing the number of cell washing, the sensitivity increased and the optimum was observed after two times washing. Furthermore, the inhibition percentages increased with the increase of incubation time for the cells washed one or two times, which indicates that such state of cells reflects accurately toxicity of chemicals. Over three times washing, however, led to the decrease of sensitivity, probably due to significant cell damage 
of the strain DSM 7151.

In this connection, we also performed cell washing with ASW or $0.5 \mathrm{M} \mathrm{NaCl}$ solution to make clear the influence of washing solution. As shown in Table 2, the use of ASW led to minor reduction of BLI compared to that of $0.5 \mathrm{M} \mathrm{NaCl}$ solution, irrespective of whether the cells were grown in LM or LB medium. From the comparison of growth medium, more serious reduction of BLI was observed in the cells grown in LB medium in comparison with

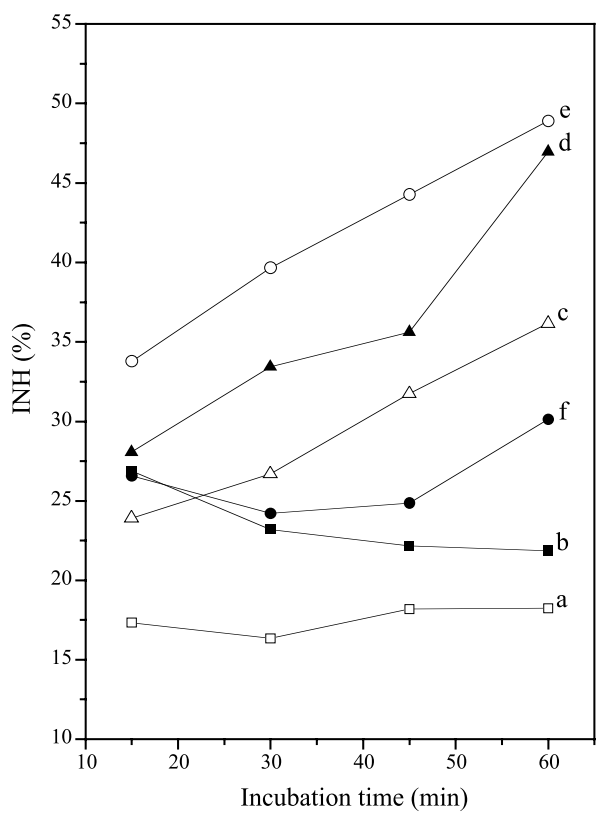

Fig. 3. Effect of Cell Washing for the Sensitivity against SeaNine 211

The cells were grown in LM medium for $18 \mathrm{hr}$, from which $1 \mathrm{ml}$ culture was diluted 100 folds with LM medium freshly prepared $(\square$, a) or with ASW $(\boldsymbol{\square}, \mathrm{b})$. For 4 each of $1 \mathrm{ml}$ culture, we carried out the centrifugation $(\triangle, c)$ followed with washing with ASW by one time $(\boldsymbol{\Lambda}$ d), two times $(O$, e $)$, and three times $(\boldsymbol{O}, \mathrm{f})$. Each cell pellets thus manipulated was suspended in ASW and diluted 100 folds with ASW. Final concentration of SeaNine 211 added to each cell suspension was $0.3 \mathrm{mg} / \mathrm{l}$. BLI values of the cells just before mixing were set to initial value of BLI and after mixing their changes were followed at $15,30,45$ and $60 \mathrm{~min}$ of incubations. All of the values were obtained from triplicate experiments, averages of which were only described. that of LM medium (Table 2). In conclusion, the cells that were grown in LM medium and washed two times with ASW resulted in the highest sensitivity among them, probably due to not only low content of medium components but also little damage of cells through centrifugation with ASW.

\section{Effect of Cell Dilution}

The viable cell numbers of $V$. fischeri grown in LM medium for $18 \mathrm{hr}$ were around $1.5 \times 10^{8} \mathrm{cfu} / \mathrm{ml}$. To make the cell assay more sensitively, we tried to obtain a suitable cell density through dilution of cells using ASW. INH (\%) of BLI was determined at 15 and $30 \mathrm{~min}$ of incubations in the presence of $0.4 \mathrm{mg} / \mathrm{l}$ SeaNine 211. As shown in Fig. 4, the sensitivity of present assay was increased almost linearly with the increase of dilution folds by ASW. Over 128 folds dilution, INH (\%) decreased gradually, in which the significant deviation of the data was also observed. As a consequence, dilution of the cells by 128 folds with ASW afforded the highest sensitivity. After about 128 folds dilution of the cells by ASW, the cell density and BLI resulted in about 1.0-1.5 $\times$ $10^{6} \mathrm{cfu} / \mathrm{ml}$ and $8-12 \mathrm{kcpm} / \mathrm{ml} \cdot \mathrm{min}$, respectively.

\section{Effect of NaCl Concentration in the Assay Me- dium}

After washing procedure, BLI of the cells suspended in various concentration of $\mathrm{NaCl}$ was followed at $0.2,15,30$ and 60 min of incubations. At each incubation time, BLI of cells increased with an increase of $\mathrm{NaCl}$ concentration until $0.3-0.4 \mathrm{M}$ and decreased over $0.5 \mathrm{M}$ as shown in Fig. 5. In the presence of $0.1 \mathrm{M} \mathrm{NaCl}$, cellular BLI was not detectable and at the same time it was too low to apply the present bioassay system at $>1 \mathrm{M} \mathrm{NaCl}$. Relatively stable and high BLI of the strain DSM 7151 was observed in $0.3-0.5 \mathrm{M} \mathrm{NaCl}$ in the incubation time of 0.2-60 min, which suggests that the present system seems to be enough sensitive to apply for samples containing toxic chemicals.

Table 2. Effect of Cell Washing with ASW or $0.5 \mathrm{M} \mathrm{NaCl}$ on the $\mathrm{BLI}^{a}$ )

\begin{tabular}{lcc}
\hline \hline & LB medium $^{b}$ & LM medium $^{c)}$ \\
\hline Before washing & $410 \pm 28$ & $2500 \pm 113$ \\
After washing with ASW & $134 \pm 12$ & $1827 \pm 84$ \\
After washing with $0.5 \mathrm{M} \mathrm{NaCl}$ & $87 \pm 9$ & $1333 \pm 22$ \\
\hline \multicolumn{2}{c}{ a) Washing was performed twice. } & Values of BLI $(\mathrm{kcpm} / \mathrm{ml} \cdot \mathrm{min})$ are the average \\
\pm standard deviations from three independent experiments. $b$ ) Incubation time for growth \\
was 8 hr. $c$ ) Incubation time for growth was 18 hr.
\end{tabular}




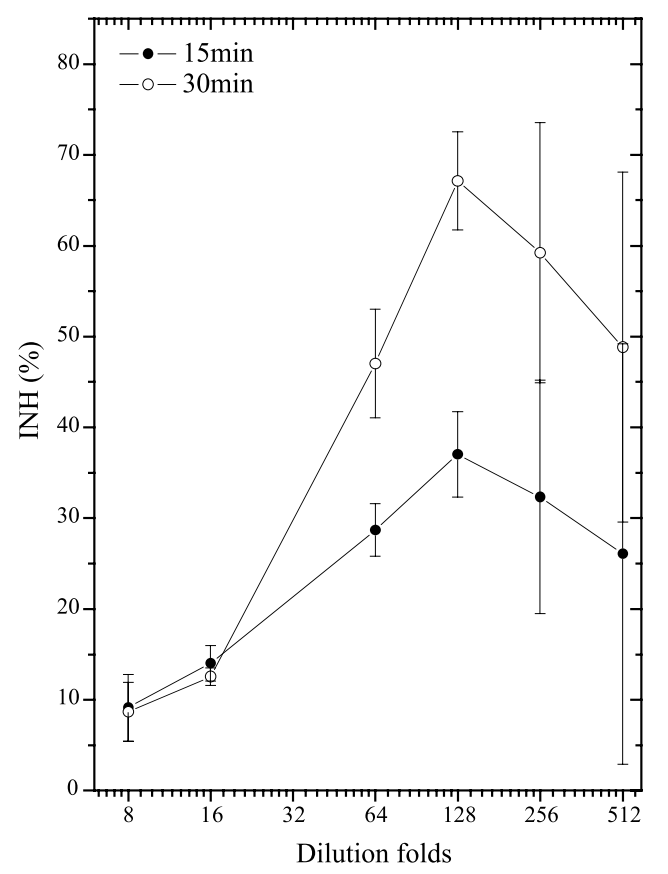

Fig. 4. Effect of Cell Dilution on the Sensitivity against SeaNine 211

Cells grown in LM medium for $18 \mathrm{hr}$ were washed twice and diluted 8-512 folds with ASW. Final concentration of SeaNine 211 added to each cell suspension was $0.4 \mathrm{mg} / \mathrm{l}$. INH (\%) at 15 (closed circles) and 30 min (open circles) of incubations was described by the averages with standard deviations from three independent experiments.

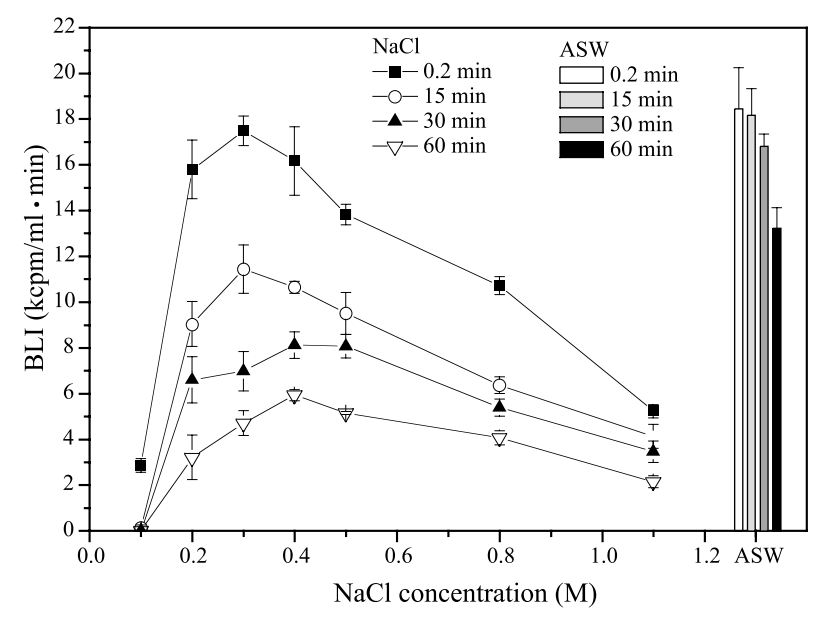

Fig. 5. Effect of $\mathrm{NaCl}$ Concentration on the BLI of V. fischeri

$V$. fischeri was grown in LM medium for $18 \mathrm{hr}$, washed twice and suspended in $0.5 \mathrm{M} \mathrm{NaCl}$ (100 folds dilution). Cell suspension thus manipulated was then adjusted to $0.1-1.1 \mathrm{M} \mathrm{NaCl}$ concentrations. The values of BLI were the averages with standard deviations from three independent incubations for 0.2 (open squares), 15 (closed triangles), 30 (open circles), and $60 \mathrm{~min}$ (closed diamonds). In addition, BLI of the cells suspended in ASW was described in white, light gray, gray, and black columns at $0.2,15,30$ and 60 min of incubation times, respectively.

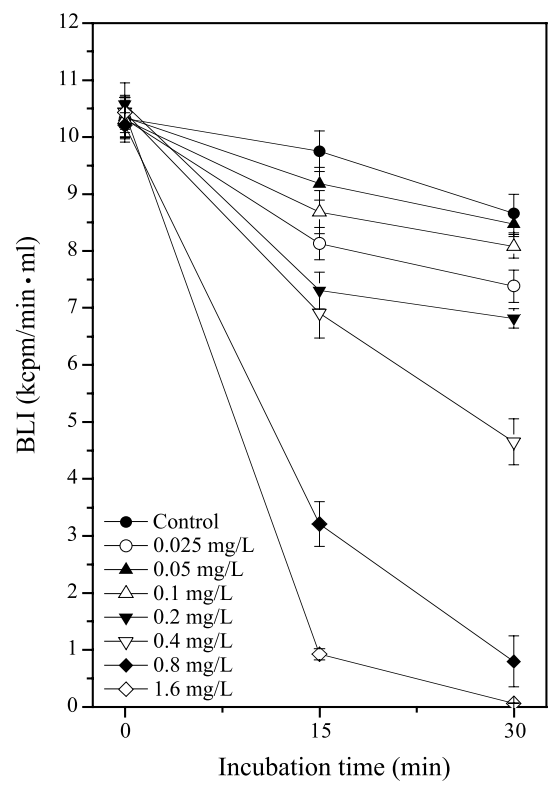

Fig. 6. Effect of Different Concentration of SeaNine 211 on Bioluminescence of $V$. fischeri

Cells grown in LM medium for $18 \mathrm{hr}$ were washed twice and diluted 128 folds with ASW. Final concentrations of SeaNine 211 added to each cell suspension were $0,0.025,0.05,0.1,0.2,0.4,0.8$, and $1.6 \mathrm{mg} / \mathrm{l}$. ASW with $1 \%$ DMSO was used as control. The values of BLI were the averages with standard deviations from three independent incubations.

As a comparison, BLI of the cells suspended in ASW was also followed and shown in Fig. 5. At each incubation time of $0.2,15,30$ and $60 \mathrm{~min}$, BLI of the cells suspended in ASW was higher than those in the presence of $\mathrm{NaCl}$ (Fig. 5). The same was true for the stability of BLI of the present strain. Furthermore, the metabolic activity of cells led to the increase of $\mathrm{pH}$ in $\mathrm{NaCl}$ solution, namely from 7.2 to 7.8 during $2 \mathrm{hr}$ of incubation, while $\mathrm{pH}$ changes of cell suspension in ASW was negligible, probably due to its buffering effect. Present finding might suggest that more comfortable hydrogen-ionic and osmotic environment for cells was created in ASW compared to $\mathrm{NaCl}$ solution. ${ }^{13,23)}$ Thus, it might be concluded that the usage of ASW has an obvious advantage for maintenance of high BLI in comparison with $\mathrm{NaCl}$ solution.

\section{EC $_{50}$ of Some Chemicals Based on the Present Assay System}

An attempt was made to examine whether the present assay system is applicable for actual contamination by toxic chemicals. After mixing different concentrations of SeaNine 211 into cell suspensions of $V$. fischeri thus manipulated, changes of BLI were analyzed as shown in Fig. 6, where BLI was 
Table 3. $\mathrm{EC}_{50}$ of Some Typical Chemicals Obtained from Present Assay System $\left(\mathrm{mg} / \mathrm{l}^{a}\right)^{a}$

\begin{tabular}{lccccc}
\hline \hline Incubation time & SeaNine 211 & $\mathrm{CuSO}_{4}$ & TBT-Cl & IPBC & Irgarol 1051 \\
\hline $15 \mathrm{~min}$ & $0.51 \pm 0.022$ & $0.77 \pm 0.06$ & $0.018 \pm 0.0013$ & $9.83 \pm 0.52$ & $>32$ \\
$30 \mathrm{~min}$ & $0.35 \pm 0.017$ & $0.22 \pm 0.02$ & $0.016 \pm 0.0011$ & $8.49 \pm 0.37$ & $>32$ \\
$\Delta(\%)^{b)}$ & $31.4 \pm 4.8$ & $39.5 \pm 5.3$ & $11.1 \quad \pm 1.0$ & $13.6 \pm 1.3$ & - \\
\hline a) Data are the averages \pm standard deviations from three independent incubations. $b) \Delta=\left\{100 *\left[\mathrm{EC}_{50}(15 \mathrm{~min})-\mathrm{EC}_{50}(30 \mathrm{~min})\right]\right\} / \mathrm{EC}_{50}$
\end{tabular}

reduced with the increase of concentration in SeaNine 211. From the extent of BLI reduction, INH (\%) values as well as $\mathrm{EC}_{50}$ can be calculated. In Table 3 we summarized the results of $\mathrm{EC}_{50}$ for toxic chemicals such as SeaNine $211, \mathrm{CuSO}_{4}$, TBT$\mathrm{Cl}$, IPBC, and Irgarol 1051. In cases of SeaNine 211 and $\mathrm{CuSO}_{4}, 0.51$ and $0.71 \mathrm{mg} / \mathrm{l}$ of $\mathrm{EC}_{50}$ values at $15 \mathrm{~min}$ of incubation decreased to 0.35 and $0.22 \mathrm{mg} / \mathrm{l}$ after $30 \mathrm{~min}$ of incubations, respectively, suggesting that toxicity of this chemical tends to be persistent. In contrast, TBT-Cl and IPBC did not afford so remarkable increase, although TBT-Cl showed quite high toxicity, which is in good accordance with the previous report that TBT-Cl is extremely toxic. ${ }^{6,12,23)}$ In response to the changes of $\mathrm{EC}_{50}$ for different chemicals, there exists, in general, three types of Light Level-Time Response Curves (LLRCs), those of which are classified from the alteration of BLI such as sharp drops and then constant, decrease almost linearly, and their intermediate. As the representative example, respective ones are phenols, heavy metals, and organic chemicals in order. Based on this classification, SeaNine 211 and $\mathrm{CuSO}_{4}$ or TBT-Cl and IPBC belong to second or third groups, respectively. In the present assay, however, such alteration was observed depending on the kinds of chemicals.

To evaluate the superiority of present assay in sensitivity, we compared $\mathrm{EC}_{50}$ values of $\mathrm{Cu}^{2+}$ with those obtained by other methods, in which $\mathrm{EC}_{50}$ with $>10 \mathrm{mg} / \mathrm{l}$ were observed through the inhibitory analyses of nitrification, respirometry, and enzyme activities. ${ }^{11)}$ These reasonable and sensitive data described here suggest that present method is quantitatively applicable for detection of such toxic chemicals.

Acknowledgements We would like to appreciate for Dr. H. Okamura, Kobe University, for providing chemicals and valuable suggestions.

\section{REFERENCES}

1) Bronstein, I., Fortin, J., Stanley, P. E., Stewart, G. S. A. B. and Kricka, L. J. (1994) Chemiluminescent and bioluminescent reporter gene assays. Anal. Biochem., 219, 169-181.

2) Daubner, S. C., Astorga, A. M., Leisman, G. B. and Baldwin, T. O. (1987) Yellow light emission of Vibrio fischeri strain Y-1: Purification and characterization of the energy-accepting yellow fluorescent protein. Proc. Natl. Acad. Sci. U.S.A., 84, 89128916.

3) McFall-Ngai, M. J. (1999) Consequences of evolving with bacterial symbionts: insights from the squidvibrio associations. Annu. Rev. Ecol. Syst., 30, 235256.

4) Ellis, R. J. and Wright, A. G. (1999) Optimal use of photomultipliers for chemiluminescence and bioluminescence applications. Luminescence, 14, 11-18.

5) Hernando, M. D., Ejerhoon, M., Fernández-Alba, A. R. and Chisti, Y. (2002) Combined toxicity effects of MTBE and pesticides measured with Vibrio fischeri and Daphnia magna bioassays. Water Res., 37, 4091-4098.

6) Wegrzyn, G. and Czyz, A. (2002) How do marine bacteria produce light, why are they luminescent, and can we employ bacterial bioluminescence in aquatic biotechnology? Oceanologia, 44, 291-305.

7) Bendriaa, L., Picart, P., Daniel, P., Horry, H., Durand, M. and Thouand, G. (2004) Versatile device for online and in-situ measurement of growth and light production of bioluminescent cells. Sens. Actuators B, Chem., 103, 115-121.

8) Froehner, K., Backhaus, T. and Grimme, L. H. (2000) Bioassays with Vibrio fischeri for the assessment of delayed toxicity. Chemosphere, 40, 821-828.

9) Fulladosa, E., Murat, J. C. and Villaescusa, I. (2005) Study on the toxicity of binary equitoxic mixtures of metals using the luminescent bacteria Vibrio fischeri as a biological target. Chemosphere, $\mathbf{5 8}$, 551-557.

10) Lange, J. H. and Thomulka, K. W. (1997) Use of the Vibrio harveyi toxicity test for evaluating mixture interactions of nitrobenzene and dinitrobenzene. 
Ecotoxicol. Environ. Saf., 38, 2-12.

11) Dalzell, D. J. B., Alte, S., Aspichueta, E., de la Sota, A., Etxebarria, J., Gutierrez, M., Hoffmann, C. C., Sales, D., Obst, U. and Christofi, N. (2002) A comparison of five rapid direct toxicity assessment methods to determine toxicity of pollutants to activated sludge. Chemosphere, 47, 535-545.

12) Fernández-Alba, A. R., Hernando, M. D., Piedra, L. and Chisti, Y. (2002) Toxicity evaluation of single and mixed antifouling biocides measured with acute toxicity bioassays. Anal. Chim. Acta, 456, 303-312.

13) Onorati, F. and Mecozzi, M. (2004) Effects of two diluents in the Microtox ${ }^{\circledR}$ toxicity bioassay with marine sediments. Chemosphere, 54, 679-687.

14) Abbondanzi, F., Cachada, A., Campisi, T., Guerra, R., Raccagni, M. and Iacondini, A. (2003) Optimisation of a microbial bioassay for contaminated soil monitoring: bacterial inoculum standardization and comparison with Microtox ${ }^{\circledR}$ assay. Chemosphere, 53, 889-897.

15) Elaine, M. B., Killham, K. and Andrew, A. M. (2001) Toxicity of mono-, di- and tri-chlorophenols to lux marked terrestrial bacteria, Burkholderia species Rasc c 2 and Pseudomonas fluorescens. Chemosphere, 43, 157-166.

16) Lajoie, C. A., Lin, S.-C., Nguyen, H. and Kelly, C. J. (2002) A toxicity testing protocol using a bioluminescent reporter bacterium from activated sludge. J. Microbiol. Methods, 50, 273-282.
17) Ren, S., Schultz, T. W. and Frymier, P. D. (2004) Evaluation of the Shk1 activated sludge bacterial luminescence inhibition assay: narcotic chemicals. Bull. Environ. Contam. Toxicol., 72, 1187-1194.

18) Ren, S. and Frymier, P. D. (2005) Toxicity of metals and organic chemicals evaluated with bioluminescence assays. Chemosphere, 58, 543-550.

19) Thomulka, K. W., Abbas, C. G., Young, D. A. and Lange, J. H. (1996) Evaluating median effective concentrations of chemicals with bioluminescent bacteria. Bull. Environ. Contam. Toxicol., 56, 446452.

20) Stauber, J. L. and Florence, T. M. (1987) Mechanism of toxicity of ionic copper and copper complexes to algae. Mar. Biol., 94, 511-519.

21) Tiano, L., Fedeli, D., Santoni, G., Davies, I. and Falcioni, G. (2003) Effect of tributyltin on trout blood cells: changes in mitochondrial morphology and functionality. Biochim. Biophys. Acta, 1640, 105-112.

22) Ecobichon, D. J. (1991) Toxic Effects of Pesticides in Casarett and Doull's Toxicology. In The Basic Science of Poisons, Fourth Edition (Mayo, O., Amdur, J. D. and Curtis, D. K., eds.), Pergamon Press, NY, pp. 565-622.

23) Zhou, X. J., Okamura, H. and Nagata, S. (2004) Bioluminescence assay of antifoulants and seawater samples using Vibrio fischeri cell. Proc. 6th AsiaPacific Mar. Biotech. Conf., 63-69. 